ROCZNIKI NAUK SPOŁECZNYCH

Tom 12(48), numer $2-2020$

DOI: https://doi.org/10.18290/rns20482-2

REV. RAFAŁ JAKUB PASTWA

\title{
FACEBOOK PROFILES OF MAJOR TV NEWS STATIONS IN POLAND ON JUNE 4, 2019
}

Mass communication involves constant alternations due to technological development and cultural trends. It is even difficult to assess the extent of media impact on societies, social groups or individuals. Nevertheless, it is not an accidental process but the one which seems to be frequently created and manipulated in order to achieve intended objectives. Thus, it is crucial to understand the roles, functions and tasks of the media. As Mrozowski emphasizes-the role of the media constitutes for their overall contribution to the functioning of a given society. The functions of the media are the results of the implemented methods. Whereas the tasks of the media are the planned actions resulting from an adopted goal or a variety of goals. This leads to a specific, intended effect or numerous effects. ${ }^{1}$ In this sense, however, the category of media functions would be indirect, concern actions initiated for a specific purpose and with a specific intention to bring specific results. On the other hand, the results may not always be in accordance with the intended goal. However, this goal always affects the role of the media in shaping the post-modern society. ${ }^{2}$ Therefore, following Mrozowski's indicative thought one should distinguish intentional functions, assigned functions, and performed functions of the media. The former result from the assumptions and intentions of the sender and the effects that they want to achieve. In addition, in some situations, these functions may determine media activity. The assigned functions constitute for nothing more than the content and form of the media message used for the optimal implementation of the planned effects. ${ }^{3}$ In turn,

Rev. Dr. Rafal Jakub Pastwa-Department of Media Workshop and Axiology, The John Paul II Catholic University of Lublin; address for correspondence: Al. Racławickie 14, 20-950 Lublin; e-mail: rafal.pastwa@ kul.pl; ORCID: https://orcid.org/0000-0001-9470-5156.

${ }^{1}$ M. Mrozowski, Media masowe. Wtadza, rozrywka i biznes (Warszawa: Wydawnictwo ASPRA-JR, 2001), 110.

${ }^{2}$ Cf. Mrozowski, Media masowe.

${ }^{3}$ Cf. Mrozowski, Media masowe, 111. 
the performed functions mean the real impact of the message on the media user. But the effect may not be consistent with the intention of the sender.

In a world dominated by the new media model, direct participation fades away in the media sphere. There is no place for the traditional division into sender and recipient, producer and consumer anymore. The media mentality absorbs more areas, those regarding politics, power, culture and art, intellectual life, sport, entertainment, Catholic church institutions, NGOs, and many more. Therefore, a process of mediatisation, which concerns all areas of life, should be recognized in this situation as it was correctly stated by M. Molęda-Zdziech. ${ }^{4}$

According to Stig Hjarvard, mediatisation is a two-way process in a post-modern culture. On one hand it is a process in which the media are becoming an independent institution, with their own logic. Moreover, other social institutions must adapt to it. On the other hand, media are becoming an integral part of other social spheres such as politics, family, work or religion, which is perceived on the level of interactivity of the processes indirectly triggered by the media. ${ }^{5}$ Much space has long been devoted to the sphere of mediatization of political life. Today, almost everything a media user learns about politics comes from the area of new media. ${ }^{6}$ As Piontek emphasizes, media visibility is not completely related to physical presence. ${ }^{7}$ It seems that visibility in the area of new media, achieved by proper usage of them, may be sufficient for image creation.

Various processes, which occur as a consequence of the media influence on the functioning of societies, social groups and individuals, in the era of mass culture, are worth a thorough investigation. In this context, the issue of media metaphors coined by Hjarvard and precisely described by Molęda-Zdziech, should be elaborated on. The first type of metaphor is a reality in which the media are understood as channels of symbol transmission from sender to recipient. Second type metaphors emphasize that a given medium determines the adaptation of the message adequately to the relationship between sender and recipient. Therefore, the media are understood as languages of communication. In the third type of metaphors, the media are understood as an environment of global communication, with the simultaneous strengthening of individualism through the

\footnotetext{
${ }^{4}$ Cf. M. MolęDA-ZDZIECH, Czas celebrytów. Mediatyzacja życia publicznego (Warszawa: Difin SA, 2013), 15-6.

${ }^{5}$ P. HJARVARD, "The Mediatization of Society. A Theory of the Media as Agends of Social and Cultural Changes," Nordicom Reviev 29, no. 2 (2008): 105.

${ }^{6}$ Cf. P. HJARVARD, "The Mediatization of Society. A Theory of the Media as Agends of Religious Changes," Northern Lights 6, no. 1 (2008): 12-4.

${ }^{7}$ Cf. D. PIONTEK, "Personalizacja rywalizacji wyborczej w kampanii parlamentarnej," Roczniki Nauk Społecznych 4 (40), no. 3(2012): 115.
} 
usage of latest technologies that allow to bypass spatial and time barriers. ${ }^{8}$ The trend, in which the youth choose electronic media, whereas the elder-traditional ones, including television, is still maintained. Although, a new kind of a medium, which completely engages its users, is expected to be created in the future. ${ }^{9}$ One should not underestimate the role of traditional media which try to find their place in the new reality. Development of digital and mobile technologies are the key factors which cause people to devote their time to consuming the content proposed by the new media. This trend is rising and the use of online content outside the workplace and outside home triggers more than just massification, but also determines the possibility of being constantly "updated" on Instagram, Facebook or other services. On the other hand, limited access to this content and platforms, causes digital exclusion.

Undoubtedly, the popularity of a particular formula is influenced by the attractiveness of the format. This is created by receivers through viewership, click-through rate, multitude of comments, number of views or audience. ${ }^{10}$ However, the importance of information does not have to be determined by the absolute image and status of a journalist, commentator or blogger. Of course, what counts is the network of connections and the attractiveness of the message, but many issues are determined by the taste of the media participants and their worldview. The access to a dedicated group of recipients should not be underestimated.

\section{IDENTITY MINDSET}

M. Lisowska-Magdziarz, a media expert, emphasizes the development of the so-called, identity narrative "and other different areas of political persuasion, education or even marketing." The researcher claims that:

The narrative proposes one dominant, exclusive, non-alternatively and positively evaluated, specific model of patriotism. The model is associated with axiologically value-related attitude to human identity and to possible efforts for its own construction or modification. The basic component of this homogeneous, inalienable and unchanging, although at the same time (paradoxically) threatened by various external cultural and political influences, identity is the sense of relationship with the national community—adhering to conservative traditions and values. A particularly

\footnotetext{
${ }^{8}$ Cf. MolęDA-ZDZiech, Czas celebrytów, 35.

${ }^{9}$ Cf. J. DĄBAŁA, Media i dziennikarstwo. Aksjologia - warsztat-tożsamość (Kraków: Universitas, 2014), 34-5.

${ }^{10}$ Cf. MolęDA-ZdZiech, Czas celebrytów, 140-1.
} 
important aspect of the issue is the relationship between identity defined in this way, which is convincingly and enthusiastically proposed to the recipients by the right-wing and conservative media. Another important aspect are the definitions of cultural diversity and the descriptions of a dangerous "other" or "an alien" (understood as someone from another country, culture or ethnic community) introduced by them. ${ }^{11}$

The author emphasizes that the intensification of identity discourse in Polish public sphere is clearly associated with the influx of migrants to Europe. In her opinion, the identity narrative "is the result of deliberate fuelling triggered by right-wing politicians who see the possibility of public opinion manipulations in strengthening the fear of immigrants. While, on the other hand, shaping the closed, essentialist version of national identity is perceived as potential for long-term social engineering." 12

Indeed, social media-though not only them, have become, as Lisowska-Magdziarz claims, carriers of identity discourse and the consolidation of a certain form of separateness. However, it seems inaccurate to link the identity narrative with one side of the political or ideological scene, and to connect it only with migration processes and attitude towards strangers. A certain, definite forms of patriotism and exclusion of "the others" are not only present in conservative circles. A person or a social group that fails to identify themselves with the views of people choosing a particular type of media, instantly becomes "the other." This refers to new-tribal mindset and also with highly noticeable social and ideological division. This is due to the increase in the attitudes of extreme individualism and the creation of a culture of "building on distrust."13

The fact that conservative environments do not allow negotiation of certain values, separate thinking about gender, race or religion, does not mean that liberal or leftist environments allow a different kind of thinking about these issues. Identity media in our country are therefore, the domain of both the conservative communities and the remaining ones. The identity of a given group of recipients is determined by the ideological closeness with a specific group, relating to a specific medium or media. This was sometimes demonstrated by the very aggressive

\footnotetext{
${ }^{11}$ M. LisowsKa-MagdZiARZ, "Medialne narracje tożsamościowe i stosunek do Innego - problem społeczny i dylemat badawczy," Media, Biznes, Kultura 1(4) (2018): 48, Accessed July 1, 2019, file:///C:/Users/LublinQ/Downloads/5-MBK\%20no.\%204\%20(2).

${ }^{12}$ Lisowska-MagdZiarz, "Medialne narracje," 48.

${ }^{13}$ Cf. R. PASTwA, "An Individual in the World of Total Communication - in Other Words, Every-Day Reality of the Contemporary Nomads in the Reality Based on Distrust," in Communication, Education, Culture, ed. M. Podkowińska (Presov: Pro Communio, 2018), 189.
} 
reactions of some public figures after the announcement of the European Parliament election results in Poland. ${ }^{14}$

Polarization and identity division in the Polish society had an impact on record high turnout and the election result itself. ${ }^{15}$ However, the increasing level of anxiety in relation to the uncertain future, was also noticed in other countries. ${ }^{16}$ The identity narrative, regarding the interpretation of experience and history, has a significant impact in this respect. ${ }^{17}$

The above mentioned insecurity is largely influenced by destabilization in the labour market, work automation, ${ }^{18}$ and distrust. All of the above constitute for the main effect of mediation. ${ }^{19}$ Consequently, the employers are given a 75 -percent trust levels by the employees..$^{20}$ However, it is not self-interest that decides on an individual vote, but whether the party's and candidate's program matches the voter's specific identity. The issue is even more significant than the notion of image programming of a given politician. ${ }^{21}$ The division of identity concerns public debate, language and the assessment of specific historical events. 'If the opponent is pronounced guilty of evil intentions, proving the truth becomes unnecessary, ${ }^{22}$ On top of that, Bauman emphasizes that "once powerless policy, usually moves into area of collective memory," which is an area more susceptible to manipulation and management'. ${ }^{23}$ In the further part of his analysis, he supports Lowenthal's idea that this is the easy path to cultivate heritage. It is based on a short-term competition, in which being the best most effective, celebrating things belonging to a given group or community, while excluding everything else, is the key. Therefore, heritage is focused on building a collective sense of pride

\footnotetext{
${ }^{14}$ Cf. T. ŁaWNICKI, "Była minister kultury ostro o obrażaniu wyborców, którzy "cenią sobie 500+,"” “Natemat.pl,” accessed July 2, 2019, https://natemat.pl/274277,krystyna-janda-obrazawyborcow-pis-malgorzata-omilanowska-komentuje.

${ }^{15}$ Cf. S. SęKOWSKI, "Eurowybory wygrała polaryzacja," Nowakonfederacja.pl, accessed July 8, 2019, https://nowakonfederacja.pl/eurowybory-wygrala-polaryzacja/.

${ }^{16}$ Cf. R. PAStwa, "Zaufanie w kryzysie, czyli 'kultura budowania na nieufności.' Próba analizy zjawiska na podstawie '2017 Edelman Trust Barometer' z uwzględnieniem odniesienia do mediów," Roczniki Nauk Spotecznych 9(45), no. 3 (2017): 109.

${ }^{17}$ Cf. A. Stolarz, "Dzielenie się pamięcia." Praktyka i teoria historii mówionej (Lublin: Instytut Europy Środkowo-Wschodniej, 2016), 137-42.

${ }^{18}$ Cf. Z. Bauman, Retropia. Jak rządzi nami przeszłość, tłum. K. Lebek (Warszawa: Wydawnictwo Naukowe PWN, 2018), 64-5.

${ }^{19}$ Cf. Pastwa, "Zaufanie w kryzysie," 109.

${ }^{20}$ Cf. Edelman Trust Barometer, 2019, https://www.edelman.com/trust-barometer.

${ }^{21}$ Cf. M. Cichosz, (Auto)kreacja wizerunku polityka na przykładzie wyborów prezydenckich w III RP (Toruń: Wydawnictwo Adam Marszałek, 2007), 60-2.

${ }^{22}$ Cf. Bauman, Retropia, 114-5.

${ }^{23}$ Cf. BAUman, Retropia, 116.
} 
in specific events, sets goals for the future. Thus, it shows clear differences in relation to political opponents or people thinking and living differently. ${ }^{24}$

Given this context, it is difficult to underestimate the increase in distrust towards major types of institutions. According to a report prepared by the Edelman Trust Barometer 2017, the implosion of trust has particularly affected the media, seen globally as an institution, and also in Poland itself. Only $43 \%$ of the respondents trusted the media globally. However levels of trusts in social media were even lower and constituted for just above 40 percent. According to the study $57 \%$ of respondents trusted traditional media. On the other hand, search engines received the highest level of trust, which was at 64\%. In Poland, only $31 \%$ of the surveyed people trusted the media. Therefore, it is not surprising, that the representatives of the Polish society trusted people, who shared the same worldview, with the same, similar or relatively stronger identity. ${ }^{25}$

The strength of traditional media, especially television, now inseparable from the new media, can be demonstrated by the incident related to this year's Champions League final. During the match, Kinsey Wolanski, dressed in a swimsuit, ran onto the pitch. This way, she decided to advertise a YouTube channel, run jointly with her partner. Within a few hours, her Instagram profile grew in over 2 million followers. Shortly after these events, Darren Rovell, a sports marketing expert, reported that the advertising equivalent of the YouTube channel was almost $\$ 4$ million thanks to K. Wolanski's actions. ${ }^{26}$

Since 1989, the media market in Poland has changed fundamentally. In the era of the market economy. The media market is perceived as a group of enterprises and, on the other hand as means of mass communication..$^{27}$ After June 4, 1989, the entire social situation has changed, and there has been a systemic transformation. The Catholic Church, did not remain neutral in the mediation between the communist authorities and the opposition, also during the elections in the June. ${ }^{28}$ The current situation of the Church, as well as the position of authorities, differs significantly from that of the $90 \mathrm{~s}$. In addition, the mediatization process has

\footnotetext{
${ }^{24}$ Cf. Bauman, Retropia, 103-4.

${ }^{25}$ Cf. Pastwa, "Zaufanie w kryzysie," 108.

${ }^{26}$ Cf. "Instagram usunął konto Kinsey Wolanski, która wbiegła na murawę podczas finału Ligi Mistrzów," "Wirtualnemedia.pl," accessed June 28, 2019, https://www.wirtualnemedia.pl/artykul/insta gram-usunal-konto-kinsey-wolanski-ktora-wbiegla-na-murawe-podczas-finalu-ligi-mistrzow.

${ }^{27}$ Z. BAJKA, "Rynek mediów w Polsce," in Dziennikarstwo i świat mediów. Nowa edycja, eds. Z. Bauer, and E. Chudziński (Kraków: Universitas, 2012), 183-206.

${ }^{28}$ Cf. R. ŁatKA, "Przegranie okazji byłoby klęską,” Gość Niedzielny, no. 22(2019), 44-5.
} 
affected so many public spaces, including church institutions. It affects the view of modern individuals on the events of the transformation period. ${ }^{29}$

Generations which have not witnessed the events of the transformation gain their knowledge on this subject based on media coverage. It also affects (the extent of this impact would be worth further examination) the generation which remembers the 1989 events. Freedom and Civil Rights Day established by a resolution of the Sejm of May 24, 2013, commemorating the first partially free elections to the Sejm after the Second World War and completely free to the Senate, gave way to the Day of Freedom and Solidarity created in the media. Although, the attitude to June 4, 1989 and the period of political transformation results from belonging to a specific identity environment. ${ }^{30}$

The main research goal of this article was to examine the way of presenting the events dated on June 4, 2019 on the Facebook fanpages of major TV news stations in Poland, namely: TVN24, TVP Info, Polsat News. ${ }^{31}$ Due to high popularity of Facebook in recent years, ${ }^{32}$ the official accounts of these TV stations, which are available to everyone, were named the subject of the analysis. ${ }^{33} \mathrm{~A}$ single post was made to the research unit. The choice of the time-limit was deliberate, all posts from June 4, 2019 were examined.

Research questions concern the frequency of information and ways of using the communication strategy in informing about the 30th anniversary of partially free elections in Poland. Besides, the fact of informing and the nature of the posts seemed immensely interesting in the research.

Two hypotheses were made in the study. According to the first one, the events of June 4, 2019 drew attention to the accounts of the main TV news sta-

${ }^{29}$ Cf. R. PASTwA, "Mediatyzacja instytucji Kościoła i strategia personalizacji w kontekście zjawiska prywatyzacji wizerunku księdza na Facebooku," Biuletyn Edukacji Medialnej 2(2018): 82-97.

${ }^{30}$ CBOS, Polacy o Magdalence, Okragłym Stole i poczuciu zdrady. Komunikat z Badań (Warszawa, 2010), 1-19, accessed July 1, 2019, https://www.cbop.pl/SPISKOM.POL/2010/K_101_10.

${ }^{31}$ P. PALLus, "Rok 2018: Polsat najpopularniejszy, zyskały główne kanały TVP," Businessinsider.pl, accessed June 10, 2019, https://businessinsider.com.pl/media/tv-radio/najpopularniejsze-programy-i-kanaly-w-2018-roku/24lx5c1. Major news stations fell in 2018, but TVN24 turned out to be more popular than the public TVP Info channel. Far behind them Polsat News was included in the ranking. The market share in 2018 was: TVN24-4.14\%, TVP Info-3.43\%, Polsat News-1.12\%.

${ }^{32}$ Cf. A. ChabrzyK et al., "Facebook. Informacje ogólne," in Przewodnik po Social Media w Polsce, \#SocialMediaAB 2019/2020, 7, accessed December 18, 2020, https://iab.org.pl/wp-content/uplo ads/2020/01/IAB-Przewodnik-po-Social-Media-w-Polsce-2019-2020.pdf; Cf. NapoleonCat, "Facebook Users in Poland June 2019," accessed December 20, 2020, https://napoleoncat.com/stats/facebook-users-in-poland/2019/06.

${ }^{33}$ Facebook profile TVN24.pl is liked by 1387808 and followed by 1347511 users. The profile of tvp.info is liked by 350,953 users and watched by 349,566 users. Polsatnewp.pl page is liked by 156777 users, while 161439 users follow it. Data from: July 1, 2019. 
tions on Facebook, because of the social importance of the event. The second hypothesis indicates that due to certain political preferences, to which specific TV news stations are inclined, the events of June 4, 2019 were presented in different ways.

A quantitative and qualitative content analysis served as the basic research method. The method seems to be legitimate in relation to the sphere of communication, in which the key elements shaping its content and form are analysed.

\section{RESULTS}

The analysis covered Facebook fanpages, the content of which was publicly available to all interested internet users, of three major news TV stations: TVN24.pl, tvp.info and polsatnews.pl. On June 4, 2019, all three stations published a total of 16 posts on their Facebook pages.

Table 1. Number of posts published on Facebook pages on June 4, 2019

\begin{tabular}{|l|c|c|}
\hline \multicolumn{1}{|c|}{ Facebook name } & Total posts on June, 4. & Posts related to June, 4. \\
\hline TVN24@tvn24pl & 6 & 3 \\
\hline tvp.info@tvp.info & 7 & 2 \\
\hline polsatnews.pl@polsatnewspl & 3 & 1 \\
\hline
\end{tabular}

Source: Own study.

A variation in the number of posts published on Facebook by individual stations can be observed. Most posts were published on the tvp.info and TVN24 pages, whereas a significantly lower amount of them was published on the polsatnews.pl page. 
Table 2. Post topics on the Facebook pages

\begin{tabular}{|l|l|}
\hline \multicolumn{1}{|c|}{ Facebook page name } & \multicolumn{1}{c|}{ Post topics } \\
\hline \multirow{2}{*}{ TVN24@tvn24pl } & $\begin{array}{l}3 \text { - concerning June, } 4 . \\
1-\text { cruiser in the port of Venice } \\
1-\text { Jacek Sasin the new deputy minister } \\
1-\text { weather forecast }\end{array}$ \\
\hline \multirow{2}{*}{ tvp.info@tvp.info } & $2-$ concerning June, 4. \\
& $1-$ Birgfellnera hearing \\
& $1-$ aggression against a drunk man \\
& $1-$ Rapper Jay-Z becomes a billionaire \\
& $1-$ Lower unemployment rate in Poland \\
& $1-$ suspension of general Franco's exhumation \\
\hline polsatnews.pl@polsatnewspl & 1 - concerning June, 4. \\
& $1-$ Trump broke the protocol in Great Britain \\
& $1-$ Prime Minister on the decision of Minister \\
& Czerwińska \\
\hline
\end{tabular}

Source: Own study.

Local policy was among the leading topics on all analysed pages but there were also some news from abroad. This means that the Facebook page of each channel cares for thematic diversity so as to reach users of different ages and interests. The selection of topics and the way they tend to be presented assumes the implementation of the intended functions of the media. The "setting up" of a Facebook profile, and therefore the actions resulting from the adopted goal, lead to a certain effect. Taking the above into consideration, the thematic distribution of posts that were published on June, 42019 on the studied fanpages should be thoroughly analysed.

Table 3. Percentage of posts on the Facebook pages of individual channels concerning the events of June 4, 2019

\begin{tabular}{|l|c|}
\hline \multicolumn{1}{|c|}{ Facebook page name } & $\begin{array}{c}\text { Percentage of posts regarding the events } \\
\text { of June 4 }\end{array}$ \\
\hline TVN24@tvn24pl & $50 \%$ \\
\hline tvp.info@tvp.info & $28,5 \%$ \\
\hline polsatnews.pl@ polsatnewspl & $33 \%$ \\
\hline
\end{tabular}

Source: Own study 
It should be assumed that the number of published posts regarding June, 42019 translates into the policy of the TV channel in the perception of the $30^{\text {th }}$ anniversary of partly free elections in Poland. Due to certain political preferences, the TV channels, also through published Facebook posts, express their attitude towards events, people and express their political preferences. Based on the percentage of posts concerning the events of June 4, 2019, as seen on Facebook pages of individual channels, it can be concluded that for TVN24.pl the celebration of June 4 was so important that $50 \%$ of all posts published on that day were dedicated to the topic. In case of polsatnews.pl, the studied events were covered in by the total of one-third of the Facebook posts, on that day. It is worth noting that the least interest in the topic was indicated at the official Facebook page of the public TV channel-tvp.info. This means that there was no priority in emphasising the events for the TV station and that the objectives of the station were met. The official profile of the public station dedicated only $28.5 \%$ of its posts to the events of June 4, 2019, it was similar also in the context of the 30th anniversary of the events of the 1989. It is worth mentioning that amongst all, the highest total daily number of posts was published on tvn.info.pl Facebook page.

It should be noted, based on the Agenda-setting theory, that the mass media shape the agenda of political campaign topics, influencing their importance among media users and the potential voters. ${ }^{34}$ Agenda-setting is a multi-faceted and complex phenomenon. It includes prioritization, event recognition and other issues of greater or lesser importance. Thus, mainstream news media influence the way the public thinks and behaves. ${ }^{35}$ However, with the advent of digital media, the agenda-setting process between media and the public has become more complex. This happens because media users obtain information through a variety of new media according to individual preferences. The digital news agenda, in turn, influences the agenda of the traditional news media. ${ }^{36}$ The mass media not only influences the setting of the political agenda,${ }^{37}$ but also shifts the importance of the problem or topic from media agenda to other topic, such as

\footnotetext{
${ }^{34}$ Cf. A. SzTAJDEL, "Medialny porządek rzeczy - agenda setting w mediach lokalnych," in Media w edukacji. Obszary lokalności - różnorodność wspótczesności, ed. A Roguska (Siedlce: Fundacja na rzecz dzieci i młodzieży "Szansa," 2013): 69.

${ }^{35}$ Cf. SzTAJdel, "Medialny porządek rzeczy," 68-71.

${ }^{36}$ Cf. Y. Kim, Y. KiM, and P. ZHOU, "Theoretical and Methodological Trends of Agenda-Setting Theory. A Thematic Analysis of the Four Decades of Research," The Agenda Setling Journal 1, no. 1 (2017): 8-9.

${ }^{37}$ Cf. E. NowaK, "Rola mediów masowych w ustanawianiu agendy politycznej," in: Agendasetting teorii i praktyce politycznej, ed. E. Nowak (Lublin: Wydawnictwo Uniwersytetu Marii Curie-Skłodowskiej, 2013), 39-73.
} 
for instance a topic of public importance. ${ }^{38}$ In addition, the content published in social media by media institutions and private users is then shared and duplicated, which contributes to the fluctuation of topics within the so-called intermedia agenda. ${ }^{39}$

The media often hold competing views, and people choose sources they agree with. ${ }^{40}$ Secondly, social environment and other people have a greater influence on the opinion formation than the media. ${ }^{41}$ This is related directly to the culture of distrust, which is the main effect of mediatization. ${ }^{42}$ Hence, based on the above analyses, the transfer process should also be considered a phenomena and the mechanisms from the real world to the world of media. ${ }^{43}$

Both the quantity and quality of the texts published by the surveyed portals on June 4 prove the rank of the anniversary of the events from 30 years ago, and also affect its importance in the minds of social media users, in this case Facebook. Certainly for TVN24 the anniversary of June 4, 1989 was of a great importance, in the context of the ambivalent attitude of politicians from the ruling option to the period of the political transformation in Poland, according to the data in the tables. In turn, for the government-friendly station managing the TVP Info portal, events from 30 years ago, associated with the activities and politicians supported by the Civic Coalition camp. Thus, the published content depends on the programming line of the other media. On the other hand, such a small amount of information on the first part of free elections in Poland may suggest the existence of some problems in the area of identity narrative. In this context, attention should be paid to the phenomenon of new mediatization, where the communication process is characterized by new forms of differentiation and dependence. ${ }^{44}$ This process is favored by institutionalized media, which use specific time and cultural

${ }^{38}$ Cf. KIM, KIM, and ZHOU, "Theoretical and Methodological Trends," 11.

${ }^{39}$ Cf. J. NowAK, “Agenda publiczna czy medialna? Problem statusu publikowanych oddolnie treści medialnych w ramach social media na przykładzie protestu adisucks," in Agenda-setting teorii i praktyce politycznej, 75.

${ }^{40}$ Cf. D. MCQuAIL, Teoria komunikowania masowego, tłum. M. Bucholc and A. Szulżycka (Warszawa: Wydawnictwo Naukowe PWN, 2012), 505.

${ }^{41}$ Cf. Edelman Trust Barometer 2020, Global Report, 63, accessed December 29, 2020, https://www.edelman.com/sites/g/files/aatuss191/files/2020-01/2020\%20Edelman\%20Trust\%20 Barometer\%20Global\%20Report_LIVE.pdf.

${ }^{42}$ Cf. T. Van Hout, and P. Burger, Mediatization and the Language of Journalism, 493-4, accessed December 29, 2020, https://openaccesp.leidenuniv.nl/bitstream/handle/1887/45111 /Chapter24_TVH.pdf?sequence=1; Cf. PASTwA, "An Individual in the World of Total Communication," 196-7.

${ }^{43}$ Cf. Pastwa, "Zaufanie w kryzysie," 159.

${ }^{44}$ Cf. MolęDA-ZDZIECH, Czas celebrytów, 49. 
contexts. Mass media, including Facebook, are becoming an ubiquitous environment that is a fundamental part of the social definition of reality. ${ }^{45}$

\section{CONCLUSIONS}

New media, including Facebook, give editorial teams and politicians a chance to get closer to the recipient, who is treated as a potential voter. Thus, it is significant to build closer ties with the current electorate, on the basis of an identity message, especially prior to the upcoming election campaign. It is also important to mark the difference to "others." The new media give the opportunity to interact actively in the media reality, in addition to the traditional form of communication imposed by journalists. Facebook, as one of the social media services, has become a good communication channel for politicians who can directly communicate with supporters or potential voters, strengthening the beliefs of some and trying to convince others. ${ }^{46}$ In addition, the possibility of using social media, such as Facebook fanpages allows the TV stations to contact the recipient who cannot or does not want to follow the television broadcast.

Based on the conducted analyses, which aimed to examine the editorial staff's interest in the anniversary celebrations, which took place on June 4, 2019 as reflected on the Facebook profiles of the main TV news stations in Poland: TVN24, TVP Info, Polsat News, the hypotheses were verified. The first, according to which the events of June 4, 2019 would be reflected on Facebook pages of main TV news stations due to the importance of the event, should be verified positively. The second, which assumed that due to certain political preferences the events of June 4, 2019 would be shown in different ways, should also be verified positively. On the basis of the results of the quantitative analysis presented in the article, it is worth emphasizing that both hypotheses were only partially verified and require further qualitative research.

\footnotetext{
${ }^{45}$ Cf. MolęDA-ZdZiech, Czas celebrytów, 47.

${ }^{46}$ Cf. M. ADAMIK-SzYSIAK, "Kampania wyborcza na Facebooku - studium przypadku aktywności liderów ugrupowań politycznych na Lubelszczyźnie w 2015 r.," in Oblicza wyborów. Studia wyborcze $i$ analizy kampanii parlamentarnej w 2015 r. na Lubelszczyźnie, ed. A. Łukasik-Turecka (Lublin: Wydawnictwo KUL, 2016), 100-1.
} 


\section{BIBLIOGRAPHY}

ADAMIK-SZYSIAK, Małgorzata. "Kampania wyborcza na Facebooku - studium przypadku aktywności liderów ugrupowań politycznych na Lubelszczyźnie w 2015 r.” In Oblicza wyborów. Studia wyborcze $i$ analizy kampanii parlamentarnej w 2015 r. na Lubelszczyźnie, edited by Agnieszka Łukasik-Turecka, 83-103. Lublin: Wydawnictwo KUL, 2016.

BAJKA, Zbigniew. „Rynek mediów w Polsce.” In Dziennikarstwo i świat mediów. Nowa edycja, edited by Zbigniew Bauer, and Edward Chudziński, 183-206. Kraków: Universitas, 2012.

BAuman, Zygmunt. Retropia. Jak rzadzi nami przesztość. Translated by Karolina Lebek. Warszawa: Wydawnictwo Naukowe PWN, 2018.

CBOS. Polacy o Magdalence, Okragtym Stole i poczuciu zdrady. Komunikat z Badań. Warszawa 2010, 1-19. Accessed July 1, 2019. https://www.cbos.pl/SPISKOM.POL/2010/K_101_10,pdf.

Cichosz, Marzena. (Auto)kreacja wizerunku polityka na przykładzie wyborów prezydenckich w III RP. Toruń: Wydawnictwo Adam Marszałek, 2007.

DĄBAŁA, Jacek. Media i dziennikarstwo. Aksjologia - warsztat - tożsamość. Kraków: Universitas, 2014.

Edelman Trust Barometer 2020. "Research.” Accessed June 10, 2019. https://www. edelman.com/trust-barometer.

Edelman Trust Barometer. "Global Report," 1-78. Accessed December 29, 2020. https://www.edelman.com/sites/g/files/aatuss191/files/2020-01/2020\%20Edelman\%20Trust\%20Barometer\%20Global\%20Report_LIVE.pdf.

HJARVARD, Stig. "The Mediatization of Society. A Theory of the Media as Agends of Religious Changes." Northern Light 6, no. 1 (2008): 9-26.

HJARVARD, Stig. "The Mediatization of Society. A Theory of the Media as Agends of Social and Cultural Changes." Nordicom Reviev 29, no. 2 (2008): 105-34.

Hout VAn, Tom, and Peter Burger. Mediatization and the Language of Journalism, 489-504. Accessed December 29, 2020. https://openaccess.leidenuniv.nl/bitstream/handle/1887/45111 /Chapter24_TVH.pdf?sequence=1.

"Instagram usunął konto Kinsey Wolanski, która wbiegła na murawę podczas finału Ligi Mistrzów." Wirtualnemedia.pl. Accessed June 28, 2019. https://www.wirtualnemedia.pl/arty kul/instagramusunal-konto-kinsey-wolanski-ktora-wbiegla-na-murawe-podczas-finalu-ligi-mistrzow.

KIM, Yeojin, Youngju KIM, and Shuhua ZHOU. "Theoretical and methodological trends of agenda-setting theory. A thematic analysis of the four decades of research." The Agenda Setling Journal 1, no. 1 (2017): 5-22.

LisowSKA-MAGDZIARZ, Małgorzata. "Medialne narracje tożsamościowe i stosunek do Innego - problem społeczny i dylemat badawczy." Media, Biznes, Kultura, no. 1 (4) (2018): 47-52. Accessed June 28, 2019. file:///C:/Users/LublinQ/Downloads/5-MBK\%20nr\%204\%20(2).

ŁATKA, Rafał. "Przegranie okazji byłoby klęską.” Gość Niedzielny, no. 22 (2019): 44-5.

ŁAWNICKI, Tomasz. "Była minister kultury ostro o obrażaniu wyborców, którzy 'cenią sobie 500+.", Natemat.pl, July 2, 2019. https://natemat.pl/274277,krystyna-janda-obraza-wyborcow-pismalgorzata-omilanowska-komentuje.

McQuaIL, Denis. Teoria komunikowania masowego. Translated by Marta Bucholc, and Anna Szulżycka. Warszawa: Wydawnictwo Naukowe PWN, 2012. 
MolĘDA-ZDZIECH, Małgorzata. Czas celebrytów. Mediatyzacja życia publicznego. Warszawa: Difin SA, 2013.

Mrozowski, Maciej. Media masowe. Władza, rozrywka i biznes. Warszawa: Wydawnictwo ASPRA-JR, 2001

NowAK, Jakub. "Agenda publiczna czy medialna? Problem statusu publikowanych oddolnie treści medialnych w ramach social media na przykładzie protestu adisucks." In Agenda-setting teorii i praktyce politycznej, edited by Ewa Nowak, 75-110. Lublin: Wydawnictwo Uniwersytetu Marii Curie-Skłodowskiej, 2013.

NowaK, Ewa. "Rola mediów masowych w ustanawianiu agendy politycznej." In Agenda-setting teorii i praktyce politycznej, edited by Ewa Nowak, 39-73. Lublin: Wydawnictwo Uniwersytetu Marii Curie-Skłodowskiej, 2013.

PALLus, Patryk. "Rok 2018: Polsat najpopularniejszy, zyskały główne kanały TVP.” Businessinsider.pl. Accessed June 10, 2019. https://businessinsider.com.pl/media/tv-radio/naj po pularniejsze-programy-i-kanaly-w-2018-roku/24lx5c1.

PASTwA, Rafał. "An Individual in the World of Total Communication - in other Words, Every-day Reality of the Contemporary Nomads in the Reality Based on Distrust." In Communication, Education, Culture, edited by Monika Podkowińska, 185-204. Presov: Pro Communio, 2018.

PASTwA, Rafał. "Mediatyzacja instytucji Kościoła i strategia personalizacji w kontekście zjawiska prywatyzacji wizerunku księdza na Facebooku.” In Biuletyn Edukacji Medialnej 2(2018): 82-97.

PAStwA, Rafał. "Zaufanie w kryzysie, czyli 'kultura budowania na nieufności.' Próba analizy zjawiska na podstawie '2017 Edelman Trust Barometer' z uwzględnieniem odniesienia do mediów." Roczniki Nauk Spotecznych 9(45), no. 3(2017): 155-66.

PionTEK, Dorota. "Personalizacja rywalizacji wyborczej w kampanii parlamentarnej." Roczniki Nauk Społecznych 4(40), no. 3(2012): 109-26.

SŁ̨KOwSKI, Stefan. "Eurowybory wygrała polaryzacja.” Nowakonfederacja.pl. Accessed July 8, 2019. https://nowakonfederacja.pl/eurowybory-wygrala-polaryzacja/.

Stolarz, Agata. "Dzielenie się pamięcią." Praktyka i teoria historii mówionej. Lublin: Instytut Europy Środkowo-Wschodniej, 2016.

SzTAJDEL, Agnieszka. "Medialny porządek rzeczy - agenda setting w mediach lokalnych." In Media w edukacji. Obszary lokalności - różnorodność wspótczesności, edited by Agnieszka Roguska, 67-78. Siedlce: Fundacja na rzecz dzieci i młodzieży “Szansa,” 2013.

\section{FACEBOOK PROFILES OF MAJOR TV NEWS STATIONS \\ IN POLAND ON JUNE 4, 2019}

\section{Summary}

The increase in the polarization level and identity divisions of the Polish society have become possible due to the existence of new media, including social media, especially Facebook. It is in the space of mass media where individual identity narratives, concerning the experience of individual memory of individual actors and the interpretation of history, take place. Among the important events in the recent history of Poland, which have become a part of the identity division and polarization processes, were the partially free elections on June 4, 1989. The quality and quantity of 
the material presented on the 30th anniversary of these elections on the official Facebook accounts of the main Polish TV news stations confirms that the media remain not neutral to key events and phenomena in the social space. Moreover, they contribute to deepening and consolidating certain moods and the phenomenon of polarization. The mediatization process affects not only the adaptation of individual units or institutions to the mentality of the media, but also the phenomenon of media adaptation to the expectations of its users.

Keywords: Facebook; media; new media; policy; communication; television.

\section{PROFILE GŁÓWNYCH STACJI TELEWIZYJNYCH W POLSCE NA FACEBOOKU 4 CZERWCA 2019 ROKU}

\section{Streszczenie}

Wzrost poziomu polaryzacji i podziały tożsamościowe polskiego społeczeństwa stały się możliwe dzięki istnieniu nowych mediów, w tym mediów społecznościowych, a zwłaszcza Facebooka. To w przestrzeni mediów masowych dochodzi do starcia i rozchodzenia się poszczególnych narracji tożsamościowych dotyczących doświadczenia indywidualnej pamięci poszczególnych aktorów oraz interpretacji historii. Wśród ważnych wydarzeń w najnowszej historii Polski, które wpisały się w podział tożsamościowy i procesy polaryzacji, były częściowo wolne wybory 4 czerwca $1989 \mathrm{r}$. Jakość oraz ilość prezentowanego materiału w 30. rocznicę tych wyborów przez oficjalne konta facebookowe głównych polskich telewizyjnych stacji informacyjnych potwierdza, że media nie są neutralne wobec kluczowych wydarzeń i zjawisk w przestrzeni społecznej. Przyczyniają się ponadto do pogłębiania i utrwalania określonych nastrojów i zjawiska polaryzacji. Proces mediatyzacji wpływa nie tylko na dostosowanie się poszczególnych jednostek czy instytucji do mentalności mediów, ale również na zjawisko dostosowania się mediów do oczekiwań swoich użytkowników.

Słowa kluczowe: Facebook; media; nowe media; polityka; komunikacja; telewizja. 